\title{
Composition and Emulsifying Characteristics of Grasscutter Meat from Varying Dietary Energy Levels
}

\author{
G. S. I. Wogar ${ }^{1}$, M. L. Ufot ${ }^{1}$, A. J. Henry ${ }^{1}$, I. E. Inyang ${ }^{1} \&$ E. E. Efe ${ }^{1}$ \\ ${ }^{1}$ Department of Animal Science, University of Calabar, Calabar, Nigeria \\ Correspondence: G. S. I. Wogar, Faculty member, Department of Animal Science, University of Calabar, Calabar, \\ Nigeria. Tel: 234-803-718-4125. E-mail: ikaniw@yahoo.com
}

Received: September 26, 2012 Accepted: October 12, 2012 Online Published: December 14, 2012

doi:10.5539/jas.v5n1p314

URL: http://dx.doi.org/10.5539/jas.v5n1p314

\begin{abstract}
Sixteen (16) grasscutters (Thryonomys swinderianus) used for this study had been fed, in groups of four, one of four treatment diets namely; 2000, 2200, 2400, and $2600 \mathrm{kcalME} / \mathrm{kg}$ respectively. Two grasscutters were randomly selected from each treatment group for slaughter. Equal weights $(150 \mathrm{~g})$ of meat samples collected from the forelimbs and hindlimbs of each slaughtered grasscutter were mixed, packed in waterproof plastic bags and stored overnight at $-2^{\circ} \mathrm{C}$. The chemical composition and emulsifying characteristics of the meat samples were determined. It was found that the chemical composition and emulsifying characteristics (including protein content, emulsifying capacity, water holding capacity, emulsion stability and cooking loss) of grasscutter meat from varying dietary energy levels were significantly $(\mathrm{P}<0.05)$ different. These findings indicate that the protein content and emulsifying characteristics were significantly higher for meat from grasscutters fed the $2000 \mathrm{kcalME} / \mathrm{kg}$ diet than for meat from grasscutters fed the higher dietary energy levels.
\end{abstract}

Keywords: composition, emulsifying properties, grasscutter meat, energy diets

\section{Introduction}

Hunting and trapping of wildlife animal species is a vital activity, which contributes to improving livelihoods among the rural dwellers of countries of the West Africa Sub-region. Meat from these wildlife species is sold as 'bushmeat' and is a major source of protein for the rural populations. Bushmeat is also a cherished delicacy in the diets of the more affluent populations of the cities, thus it contributes to sustainable human nutrition (Anwo, 2003; Gbolagada, 2008) and economy of the Sub-region (FAO, 2000; Taiwo et al., 2009). Studies have shown that meat from grasscutter (Thryonomys swinderianus) is the most popular and most widely acceptable bushmeat in Nigeria (Fayenuwo et al., 2003; Akinola, 2008).

The popularity of grasscutter meat is the reason for the interest in the domestication of grasscutter for large scale farming and production of meat for human consumption (FAO, 2000). Agricultural policies of some countries in the West African Sub-region presently promote the farming of grasscutter. Sustainable production of the grasscutter would depend not only on production efficiency, feed supplies and costs, but also on the optimum utilization of produce (Anjaneyulu, 2007).

Grasscutter meat has potential in the packaging industry. Optimum utilization of grasscutter meat would involve value addition, diversification of products, and processing technology aimed at creating sustained demand for products. Grasscutter meat products, which satisfy popular taste preferences and are readily available would increase the relative value and price for the meat and its products (USDA, 2004).

The suitability of meat and range of products obtainable from processing depends on the chemical composition of meat. Sausage production offers promise for diversification in the utilization of grasscutter meat. Sausage products are cured meat emulsions, the production of which depends on the protein, fat and water content of meat (Karakaya, 2006). The emulsifying characteristics of meat are important in the processing of sausage products (Anjaneyulu et al., 1994) and are determined by the chemical composition of the meat.

The level of nutrition affects the growth of animals and the composition of their meats. Karikari et al. (2009) suggested that efficient production in captivity of grasscutter with high productivity required adequate nutrition. Though grasscutters are herbivorous animals, they grow rapidly on compounded feeds (Gbolagada, 2008). Protein is important in the diet of growing grasscutters (Wogar, 2011a). Other studies have shown that metabolizable 
energy levels of 2500-2800 kcalME/kg are required in the diets of grasscutters for efficient productivity (Fayenuwo et al., 2003; Wogar et al., 2011).

The objective of this study is to determine the composition and emulsifying characteristics of grasscutter meat obtained from feeding diets of various energy levels.

\section{Materials and Methods}

The feeding of grasscutters was carried out at the University of Calabar Research Farm, while the determination of the composition and emulsifying characteristics of grasscutter meat was carried out in the Department of Animal Science laboratory, University of Calabar, Calabar, Nigeria.

\subsection{Experimental Diets}

Meat samples were obtained from four groups of (a total of 16) grasscutters which had been fed four diets (Table 1) with energy levels of $2000,2200,2400$, and $2600 \mathrm{kcalME} / \mathrm{kg}$ respectively. All diets were formulated to supply $18 \%$ dietary crude protein $(\mathrm{CP})$. The proximate composition of test diets is shown in Table 2.

Table 1. Gross composition of the experimental diets

\begin{tabular}{lcccc}
\hline \multirow{2}{*}{ Ingredients (\%) } & \multicolumn{4}{c}{ Experimental Diets (kcalME/kg) } \\
\cline { 2 - 5 } & 2000 & 2200 & 2400 & 2600 \\
\hline Cassava meal & 16.10 & 29.60 & 43.00 & 56.50 \\
Soybean meal & 13.20 & 19.70 & 26.00 & 32.50 \\
Wheat offal & 66.70 & 27.00 & 46.70 & 7.00 \\
Bone meal & 3.00 & 3.00 & 3.00 & 3.00 \\
Vitamin premix & 0.50 & 0.50 & 0.50 & 0.50 \\
Salt & 0.50 & 0.50 & 0.50 & 0.50 \\
Total & 100 & 100 & 100 & 100 \\
\hline
\end{tabular}

Table 2. Proximate composition of experimental diets

\begin{tabular}{lcccc}
\hline \multirow{2}{*}{ Nutrient (\%) } & \multicolumn{4}{c}{ Experimental Diets (kcalME/kg) } \\
\cline { 2 - 5 } & 2000 & 2200 & 2400 & 2600 \\
\hline Crude protein & $20.20^{\mathrm{a}}$ & $15.25^{\mathrm{b}}$ & $12.50^{\mathrm{c}}$ & $11.62^{\mathrm{c}}$ \\
Ether extract & $9.96^{\mathrm{a}}$ & $5.06^{\mathrm{b}}$ & $2.55^{\mathrm{c}}$ & $1.04^{\mathrm{c}}$ \\
Crude fibre & $7.99^{\mathrm{a}}$ & $6.27^{\mathrm{b}}$ & $5.09^{\mathrm{bc}}$ & $4.51^{\mathrm{c}}$ \\
Ash & 9.31 & 8.16 & 7.61 & 6.72 \\
Nitrogen free extract & $39.96^{\mathrm{c}}$ & $51.72^{\mathrm{b}}$ & $58.62^{\mathrm{a}}$ & $62.53^{\mathrm{a}}$ \\
Moisture & 14.85 & 13.74 & 13.63 & 13.58 \\
Dry matter & 87.15 & 86.46 & 86.37 & 86.42 \\
Metabolizable & $1999.34^{\mathrm{d}}$ & $2199.96^{\mathrm{c}}$ & $2399.87^{\mathrm{b}}$ & $2599.69^{\mathrm{a}}$ \\
\hline
\end{tabular}

a,b,c Treatments means not having the same superscript are significantly $(\mathrm{P}<0.05)$ different.

\subsection{Research ANIMALS}

All sixteen (16) grasscutters were fed the experimental diets for 6 months and weighed between 2.95 and $3.63 \mathrm{~kg}$ at the time of slaughter and collection of meat samples.

Grasscutter housing was cleaned daily in order to ensure an acceptable level of sanitation.

\subsection{Slaughter and Collection of Samples}

Two grasscutters were randomly selected from each of the treatments for slaughter (by electrical shock) and collection of samples from the forelimbs and hindlimbs of each slaughtered grasscutter. Equal weights $(150 \mathrm{~g})$ 
from each of these cuts were mixed for each treatment. The mixed samples were chopped into smaller pieces in a one-speed blender (Brand: National MX-491N). The chopped samples were placed in waterproof plastic bags, labeled and kept in cold storage overnight at $-2^{\circ} \mathrm{C}$.

\subsection{Chemical Analysis}

The meat samples were thoroughly mixed before being analysed for chemical composition and emulsifying characteristics. The method of Swift et al. (1961) was used to determine the emulsifying capacity of grasscutter meat, except that oil was added at the rate of $0.5 \mathrm{ml} / \mathrm{sec}$. The method of Townsend et al. (1968) was used for determination of the stability of grasscutter meat emulsions. The water holding capacity of grasscutter meat was determined by the method of Acton (1973), except that $20 \mathrm{~g}$ of meat tissue and $30 \mathrm{ml}$ of $0.6 \mathrm{M} \mathrm{NaCl}$ were used. The AOAC (1990) method was used in the analysis of meat samples for protein, fat and moisture contents. Triplicate determinations were made of the chemical composition and emulsifying properties of all meat samples.

\subsection{Statistical Analysis}

The Completely Randomized Design was used in the study. Data on the chemical composition (especially protein, fat and moisture) and emulsifying characteristics of grasscutter meat samples were subjected to analysis of variance by the method of the Genstat (2007) software. The Duncan's Multiple Range test (Steel \& Torrie, 1980) was used to separate significant means.

\section{Results and Discussion}

The results of the study show that the crude protein, ether extract, crude fibre and nitrogen free extract contents of the experimental diets (Table 2) were significantly $(\mathrm{P}<0.05)$ different. Other studies have shown that growing grasscutters are affected by the levels of protein (Wogar, 2011a), crude fibre (Wogar, 2011b) and energy (Wogar et al., 2011) in their diets.

The differences between the energy diets in respect of the composition and emulsifying characteristics of grasscutter meat are shown on Table 3.

Table 3. Composition and emulsifying characteristics of grasscutter meat from varying dietary energy levels

\begin{tabular}{lcccc}
\hline \multirow{2}{*}{ Nutrient (\%) } & \multicolumn{3}{c}{ Experimental Diets (KcalME/kg) } \\
\cline { 2 - 5 } & 2000 & 2200 & 2400 & 2600 \\
\hline Protein (\%) & $21.12^{\mathrm{a}}$ & $18.78^{\mathrm{c}}$ & $19.72^{\mathrm{bc}}$ & $20.18^{\mathrm{ab}}$ \\
Fat (\%) & 12.64 & 12.13 & 11.92 & 11.96 \\
Moisture (\%) & 48.81 & 48.85 & 48.97 & 49.00 \\
Moisture protein ratio & 2.31 & 2.60 & 2.48 & 2.36 \\
Moisture fat ratio & 3.86 & 4.03 & 4.11 & 4.10 \\
Fat protein ratio & 0.60 & 0.65 & 0.60 & 0.59 \\
Emulsifying capacity (ml/2.5g tissue) & $97^{\mathrm{a}}$ & $95^{\mathrm{a}}$ & $90^{\mathrm{b}}$ & $80^{\mathrm{c}}$ \\
Water holding capacity (ml/100g tissue) & & $64^{\mathrm{b}}$ & $70^{\mathrm{a}}$ & $44^{\mathrm{c}}$ \\
$72^{\mathrm{a}}$ & & $48^{\mathrm{b}}$ & $47^{\mathrm{b}}$ & $50^{\mathrm{a}}$ \\
Emulsion stability (\%) & $43^{\mathrm{c}}$ & & \\
Cooking loss: & & $33^{\mathrm{b}}$ & $43^{\mathrm{a}}$ & $47^{\mathrm{a}}$ \\
Total volume (ml/100g emulsion) & $37^{\mathrm{b}}$ & $11^{\mathrm{b}}$ & $16^{\mathrm{a}}$ & $15^{\mathrm{a}}$ \\
Fat volume (ml/100g emulsion) & $15^{\mathrm{a}}$ & $20^{\mathrm{c}}$ & $26^{\mathrm{b}}$ & $31^{\mathrm{a}}$ \\
Gel water volume (ml/100g emulsion) & $21^{\mathrm{c}}$ & & \\
\hline
\end{tabular}

a,b,c Treatments means not having the same superscript are significantly $(\mathrm{P}<0.05)$ different.

\subsection{Chemical Composition}

There were significant $(\mathrm{P}<0.05)$ differences between treatments in respect of the protein content of grasscutter meat. There were no differences between treatments in respect of the fat and moisture contents as well as ratios of 
moisture to protein, moisture to fat and fat to protein content of grasscutter meat. Protein was higher in meats of grasscutters fed the $2000 \mathrm{kcalME} / \mathrm{kg}$ diet than in meats from grasscutters fed other diets.

Stable meat emulsions are produced from protein, fat and moisture, with protein serving as an emulsifying agent (Karakaya, 2006). The most practical application of meat emulsion is found in the preparation of sausages.

\subsection{Emulsifying Characteristics}

There were significant $(\mathrm{P}<0.05)$ differences between treatments in respect of emulsifying capacity of grasscutter meat. The higher emulsifying capacity of meat from grasscutters fed the $2000 \mathrm{kcalME} / \mathrm{kg}$ diet is related to the higher protein content of the meat of grasscutters on that diet. The higher content of salt-soluble proteins of meats have been reported to effect higher emulsifying capacities in meat emulsions (Forrest et al., 1975; Karakaya, 2006).

There were significant $(\mathrm{P}<0.05)$ differences between treatments in respect of the water holding capacity of grasscutter meat. The higher water holding capacity of meat from grasscutters fed the $2000 \mathrm{kcalME} / \mathrm{kg}$ diet is related to the higher protein content of the meat of grasscutters on that diet, since most of the water in meats is located in the proteins of muscles (Kaufman et al., 1986).

There were significant $(\mathrm{P}<0.05)$ differences between treatments in respect of cooking losses. Smaller cooking losses were observed for meat emulsions from grasscutters fed the $2000 \mathrm{kcalME} / \mathrm{kg}$ diet. The stability of an emulsion is related to its ability to resist change in its properties under any form of pressure, including heat. Meat proteins are important in the formation of stable meat emulsions (Teddy, 2000). Emulsion stability, measured by the lower amounts of cooking loss, was best on the $2000 \mathrm{kcalME} / \mathrm{kg}$ diet. The lower amounts of cooking loss observed for meat emulsions from grasscutters fed the $2000 \mathrm{kcalME} / \mathrm{kg}$ diet is, therefore, related to the higher protein content of meat from grasscutters fed that diet.

Protein facilitates the production of a stable emulsion by bridging the water-oil interface (Xiong, 2000). The findings show that the protein levels of meat from grasscutters fed the $2000 \mathrm{kcalME} / \mathrm{kg}$ diet are related to the higher emulsification capacity, water holding capacity and emulsion stability obtained for meat from grasscutters fed that diet. The results suggest that the higher protein levels were related to the higher emulsifying properties of the meat samples studied.

\section{Conclusion}

The findings of this study suggest that feeding diets containing $2000 \mathrm{kcalME} / \mathrm{kg}$ results in higher protein content and therefore, higher emulsifying characteristics of grasscutter meat than feeding higher dietary energy levels.

\section{References}

Acton, J. C. (1973). Composition and properties of extruded, texturized poultry meat. J. Food Sci., 38, 571-574.

Akinola, A. F. (2008). Grasscutter farming: A new initiative in protein supply. An invited paper presented at Agricultural Product Development Strategy Workshop organized by Rivers State Sustainable Development Agency, held on 9-10th September, 2008, at the Elkan Terrace, 2b Abacha Road, Port Harcourt, Rivers State.

Anjaneyulu, A. S. R., Sharma, N., \& Kondaiah, N. (1994). Effect of salt and polyphosphate blends on the quality of buffalo meat patties under hot, chilled and frozen conditions. J. Food Sci. Technol., 31, 404-408. Retrieved from www.aseanfood.info/Articles/11020042.pdf

Anjaneyulu, A. S. R., Thomas, R., \& Kondaiah, N. (2007). Technologies for Value Added Buffalo Meat Products-A Review. American Journal of Food Technology, 2, 104-114. http://dx.doi.org/10.3923/ajft.2007.104.114

Anwo, J. A. (2003). Retrieved $7^{\text {th }}$ March 2010 from Grasscutter farming. Allafrica.com/../2003090301100/html

AOAC. (1990). Association of Official Analytical Chemists (p. 1298). 15th Edition. Washington D.C., U.S.A.

FAO. (1985). Small-scale sausage production. Fao Animal Production and Health Paper 52. By I. V. Savic, FAO Consultant. M-72. Retrieved from www.fao.org/docrep/003/x6556e/X6556E00.htm

FAO. (2000). World Watch List for Domestic Animal Diversity (p. 716). Retrieved from ftp://ftp.fao.org/docrep/fao/009/x8750e/x8750e03.pdf

Fayenuwo, J. O., Akande, M., Taiwo, A. A., Adebayo, A. O., Lawal, B. O., Tiamjio, A. K., \& Oyekan, P. O. (2003). Guidelines for grasscutter rearing (pp. 2-13). Ibadan: Technical Bulletin, I. A. R. \& T.. 
Forrest, J. C., Aberle, E. D., Hedrick, H. B., Judge, M. D., \& Merkel, R. A. (1975). Principles of Meat Science. W. H. Freeman \& Co. San Francisco. Retrieved from hydh.hbstl.org.cn/uploadfiles/RCMPYEGX1305255679184.pdf

Gbolagada, S. A. (2008). Grasscutter/Cane rat farming in the tropics. University of Ibadan Press, Ibadan, Nigeria.

Genstat. (2007). Lawes Agricultural Trust. Rothamsted Experimental Station, England. Retrieved from www.vsn.co.uk/software/genstat/

Hegarty, G. R., Bratzler, L. J., \& Pearson, A. M. (1963). Article Studies on the Emulsifying Properties of Some Intracellular Beef Muscle Proteins. Journal of Food Science, 28(6), 663-668. http://dx.doi.org/10.1111/j.1365-2621.1963.tb01671.x

Karakaya, M., Saricoban, C. Y., \& Lmaz, M. T. (2006). The effect of mutton, goat, beef and rabbit species and state of rigor on some technological parameters. Journal of Muscle Foods, 17(10), 56-64. http://dx.doi.org/10.1111/j.1745-4573.2006.00035.x

Karikari, P. K., \& Nyameasem, J. K. (2009). Productive performance and carcass characteristics of captive grasscutters (Thryonomys swinderianus) fed concentrate diets containing various levels of guinea grass. World Applied Science Journal, 6(4), 337-363.

Kauffman, R. G., Eikelenboom, G., Vander Wark, P. G., Merkus, F., \& Zaar, M. (1986). The use of filter paper to estimate drip loss of porcine musculature. Meat Science, 34, 282-300.

Kondaiah, N., Rao, V. K., Anjaneyulu, A. S. R., Sharma, N., \& Lakshmanan, V. (1986). Evaluation of variety meats from buffaloes for some quality parameters. J. Food Sci. Technol., 23, 113-115. Retrieved from www.aseanfood.info/Articles/11020042.pdf

NRC. (1991). Microlivestock: Little-Known Small Animals with a Promising Economic Future. Washington, DC: The National Academies Press, 1991. Retrieved from www.nap.edu/books/030904295X/html/-Cached

Steel, R. G. D., \& Torrie, J. H. (1980). Principles and Procedures of Statistics-A Biometrical Approach (2nd edn) (pp. 137-171), New York: McGraw Hill Book Co. Retrieved from www.sciencedirect.com/science/article/pii/0093691X9390319Z

Swift, C. E., Lockett, C., \& Fryar, A. J. (1961). Comminuted meat emulsions: The capacity of meats for emulsifying fats. Food Technol., 15, 468-473. Retrieved from books.google.co.uk/books?id=JiWjimQaeR0C

Taiwo, A. A., Fayenuwo, J. O., Omole, A. J., Fajimi, A. K., Fapohunda, J. B., \& Adebowale, E. A. (2009). Supplementary effect of concentrate feed on the performance and nutrient digestibility of cane-rat (Thryonomys swinderianus) fed a basal diet of elephant grass (Pennisetum purpureum). Nigerian Journal of Animal Production, 36(1), 183-186.

Teddy, S. J. (2000). Meat and Emulsifier (p. 117-119). New York: John Wiley and Sons.

Townsend, W. E., Witnauer, L. P., Riloff, J. A., \& Swift, C. E. (1968). Comminuted meat emulsions: Differential thermal analysis of fat transitions. Food Technol., 22, 319-323.

USDA. (2007). Announcement of value-added Producer Grant application deadlines and funding levels. USDA Rural Business Cooperative Service. Fed. Reg. 69, 33349.

Wogar, G. S. I. (2011a). Performance of growing grasscutters (Thryonomys swinderianus) fed cassava-based diets with graded protein levels. Journal of Agricultural Sciences, 7(5), 510-514.

Wogar, G. S. I. (2011b). Performance of growing grasscutters on different fibre sources. Pakistan Journal of Nutrition, 11(1), 51-53.

Wogar, G. S. I., Effiong, O. O., \& Nsa, E. E. (2011). Performance of growing grasscutters (Thryonomys swinderianus) fed diets with graded energy levels. Journal of Agriculture, Biotechnology \& Ecology 4(3), 134-139. Retrieved from www.universalacademicservices.org/journals/...4...3/performance-of-

Xiong, Y. L. (2000). Meat processing. In S. Nakai \& H. W. modler (Eds.), Food Proteins: Processing applications (pp. 89-145). New York: Wiley-VCH. 